\title{
Cross Border B2C E-Commerce to Greater China and the role of logistics: a literature review
}

\begin{abstract}
Purpose - This paper reviews scientific publications in the field of logistics underlying Cross Border E-Commerce (CBEC) to China. A focus on the role played in this complex process by other Countries of the Greater China is carried out. The major aim of the paper is to outline directions for future research to encourage CBEC development.
\end{abstract}

Methodology/Approach - The review is based on 32 papers published from 2002 to 2016 in international peer-reviewed journals and/or proceedings of international conferences, retrieved from bibliographic databases and science search engines.

Findings - CBEC to China is gaining increasing interest, as shown by the rising amount of publications from 2013 onwards. Within these contributions however, studies specifically investigating the relation between logistics and e-commerce, commonly acknowledged as critical, seem to lack. Many contributions are descriptive and do not provide specific insights on how to manage the complexities of CBEC logistics in this region. Stemming from the review, a set of possible development areas are identified, including distribution network design, i.e. deciding how to shape the CBEC distribution structure, and logistics outsourcing, i.e. determining whether to manage logistics activities in-house or through third parties.

Originality/Value- To the extent of the authors' knowledge, this paper is the first one to classify the existing body of knowledge on logistics supporting CBEC. Its main contribution is the critical identification of current research gaps and the proposal of key themes for future research. From a managerial perspective, it helps export and logistics managers identify the key challenges of managing CBEC logistics to Greater China.

Keywords - internationalisation, B2C e-commerce, Greater China, logistics, cross border. Paper type - Literature review 


\section{Introduction}

Over the past 30 years, China has undergone drastic changes in its economy and society which have marked the transformation of the Country into an industrial reality and turned it into the most promising and fast growing developing nation (Reuters, 2015). This evidence symbolises an historical shift: China and the other emerging Countries have eventually overcome developed Countries, including USA, Canada, Western Europe, Australia, New Zealand and Japan. The weight of western Countries' GDP over the global GDP has indeed constantly shrunk in the past decades: it accounted for $60 \%$ in the 1970 s, just over $50 \%$ in the early 2000s and is forecasted to drop to just one third by 2025 (Jacques, 2012). On the contrary, developing nations are continuously increasing their economic size, causing the world's economic centre of gravity, calculated by weighting the national GDP over each nation's centre of gravity, to shift east at the fastest rate ever (Dobbs et al., 2012). Among Eastern Countries, the dominant role played by China is mainly due to the economic growth boosted by the increasing adoption of technology. Today China is indeed the first e-commerce market in the world. With $€ 566$ billion turnover from online B2C sales, it has overtaken USA's leadership (Forrester, 2015; eMarketer, 2015). Players such as Alibaba, the major Chinese e-commerce marketplace, are revolutionising the retailing industry, getting Chinese consumers progressively more acquainted to shop online (Winters, 2016). Such figures signal China is probably the most attractive market at the moment and, due to the stagnation of the West, should be seen as an important investment opportunity by companies from all over the world. Moreover, e-commerce is possibly the most effective channel to reach China, due to the high penetration on total retail market $(13 \%)$ and the impressive average growth rate, which approximates $+50 \%$ year over year, according to the market research company Nielsen (2016). Chinese online shoppers are also inclined towards foreign products. A research by Paypal, an American company offering online payment services, reveals that over a quarter of online shoppers in China buy foreign goods via internet, especially from USA, UK but also from closer Countries like Japan and Hong Kong (Paypal, 2014). More recently, a survey conducted in China by Nielsen additionally states that $38 \%$ of customers in Tier 1 cities and $27 \%$ in Tier 2 cities rely on cross-border online purchases (2016).

The process of selling goods to a consumer located in a foreign Country by means of online channels, either directly through a proprietary website (i.e. B2C) or through a digital intermediary such as online retailers or marketplaces (i.e. B2B2C) can be referred to as Cross Border E-Commerce (CBEC). 
The increasing diffusion of CBEC as a new model for cross border trade (Wang et al., 2015a) is attracting more attention especially from practitioners and companies interested in boosting international transactions (Gessner and Snodgrass, 2015).

This topic is also receiving growing attention in the academic community, as more publications start appearing on the subject, due to the specific knowledge and competencies required to face all the challenges behind a CBEC initiative. As recognised by Gomez-Herrera et al. (2014), many barriers still exist for CBEC take-off, including linguistic and cultural differences, regulatory matters, compatibility and interoperability between online payment systems. One of the most complex issues, however, is logistics. The intangible nature of online transactions should not allow underestimating the "problem" of physically distributing the products. For many years, scholars have been debating on the importance of logistics in B2C e-commerce and there is an overall agreement that logistics is a crucial aspect of an ecommerce initiative (e.g. Cho et al., 2008, Ramanathan et al., 2014). Its relevance is such that it is often listed among the factors that might cause e-commerce failures, when not properly managed (Delfmann et al., 2002). Indeed, logistics is considered a source of competitive advantage (Visser and Nemoto, 2002) and the efficiency of the distribution network is regarded as a success factor for firms in the e-commerce market (Cho et al., 2008).

Nonetheless, the connection between logistics and e-commerce has been predominantly analysed exclusively from a national perspective and only a few studies have been conducted on CBEC logistics so far. CBEC logistics is however different from e-commerce logistics for several reasons that explain why it should be specifically investigated.

First, the distribution network of CBEC initiatives is more articulated and riskier than the one of a national e-commerce initiative, due to many factors including the longer distances to be covered and the consequent longer delivery times, the possibly higher dependence on third party logistics service providers and the impact of customs clearance procedures (Yang and Shen, 2015). Second, CBEC implies dealing with a different culture which can impact the way logistics should be managed. For instance, local habits usually determine the expected service level or the consumer propensity to return products. Moreover, specific legal requirements should be respected. These factors usually have an impact on logistics management and getting knowledgeable about this issue is a specific challenge faced by foreign companies adopting CBEC. Last, additional investments, which do not arise in national B2C e-commerce logistics and increase the complexity, could be required to better serve the destination market (e.g. extra warehouses or transit points abroad, partnerships with local players, integration of IT systems with involved partners) (Shuyan and Lisi, 2013). 
Analysing CBEC logistics is particularly important with reference to Greater China. As noted by Hensher et al. (2015) and Hou (2014), the progress of Chinese e-commerce has been so rapid that the logistics industry could not keep the pace, rather becoming a bottleneck for ecommerce development. Moreover, e-commerce demand is growing faster in lower-tier cities, located in more rural areas, and this leads to further demanding logistics tasks. (AT Kearney, 2014).

Within the CBEC field, current literature is still fragmented and has mainly investigated frontend issues, such as marketing and communication linked to a CBEC initiative to China (e.g. $\mathrm{Xu}$ et al., 2008). Some authors have also analysed divergent preferences for online and mobile payment systems (e.g.Miao and Jayakar, 2016), looked into the different legislations and fiscal policies (Bieron and Ahmed, 2012) or discussed about e-commerce platform selection (e.g. Zhang and Huang, 2015) and e-commerce website development (Lu, 2014).

Conversely, despite being an important topic that surely deserves an in-depth investigation, logistics has seldom been studied in this context. Given these premises, the present paper aims to perform a structured identification of research gaps in current literature about CBEC that acts as a trigger to the further development of this research field. In doing so, our intention is to identify and describe possible research directions in the field of Chinese CBEC logistics by defining a roadmap of key issues to address. The identification of research gaps and the consequent prioritisation of future research patterns are the main contributions of this study and the differentiating elements with previous papers in the field.

In order to reach the stated main goal, i.e. to identify key issues and research streams, a literature review has been conducted. The review allows the authors to identify and classify existing literature contributions on logistics in the field of CBEC to China. This step is fundamental to understand what is currently missing in this research field. Moreover, specific attention is devoted to the investigation of the logistics role that Taiwan and Hong Kong, as members of Greater China, could play in supporting CBEC to the region.

The paper is structured into five main sections. The next one describes the methodology applied in this study. Section 3 presents the results of the literature review, whilst section 4 discusses the main issues stemming from the analysis and identifies future research priorities. Section 5 concludes. 


\section{Methodology}

This review covers scientific contributions of the past 15 years. This timeline occurred rather spontaneously as the early 2000s can be identified as the starting years of e-commerce diffusion. In the review process, the authors decided to opt for a systematic methodology, because it allows other scholars or practitioners to assess the reliability and completeness of the study. Since our paper is the first contribution on CBEC logistics in the form of a literature analysis, we deem the systematic approach as the most appropriate to enable verification of its content or replication of the analysis. According to Cronin et al. (2008), a literature review should be conducted by following a precise sequence of steps that go from the selection of a defined review topic and the search of related literature to the selection, analysis, and critical description of the contributions. In addition, since the purpose of a systematic review is to present and discuss a complete list of the publications on a certain topic, the specific criteria used in the literature search, selection and analysis should be specified (Cronin et al., 2008). The reminder of the paragraph describes the criteria followed along the main phases of the work, i.e. the literature search, the literature analysis and the identification of gaps. More in detail, a three-step methodology was followed, consistently with recent literature reviews published on peer-reviewed logistics journals (e.g. Carter and Easton, 2011; Grubic and Fan, 2010; Mangiaracina et al., 2015a; Mangiaracina et al., 2015b; Perego et al., 2011)

Phase 1 corresponded to the literature search, i.e. the collection and selection of relevant papers, while Phase 2 implied performing an analysis of the selected contributions and discussing results. Finally, in Phase 3 research gaps and streams for future investigation were identified.

\section{Phase 1: Literature search}

Several methodological papers on literature reviews in multiple fields (e.g. Carnwell and Daly, 2001; Tranfield et al., 2003) were consulted in the preliminary phase of this study to apply an accepted protocol.

In line with previous contributions (e.g. Srivastava, 2007; Mangiaracina et al., 2015a) the literature search was therefore conducted along the following steps:

(i) Selection of a defined review topic. The context of CBEC to the Chinese region from a logistics perspective was selected as the focus of the study.

(ii) Definition of the unit of analysis. The unit of analysis was defined as a single scientific paper published in an international peer-reviewed journal or presented at 
an international scientific conference. More in detail, initially the authors intentionally put an effort in trying to exclude conference papers with the aim to privilege completed researches over preliminary findings. However, some of the most fitting contributions were found in the form of conference papers due to the novelty of this specific topic. This explains why this type of contribution was eventually included in the review.

(iii) Literature search. Similarly to Cagno et al. (2013), Perego et al. (2011), and many other authors, the search was carried out by relying on both international bibliographic databases (i.e. Scopus, ISI Web of Knowledge), and science search engines (i.e. IEEE Xplore, Google Scholar). The systematic search was conducted using a number of keywords (i.e. "B2C e-commerce", "cross border", "logistics", “distribution network", “online export", “internationalisation", "logistics risks", “challenges", "logistics outsourcing") and all their possible combinations, paired, one at a time, with our geographical focus (i.e. "Greater China”, "China”, “Taiwan”, “Hong Kong”, "Macau”).

(iv) Definition of inclusion/exclusion criteria. Different combinations of the listed keywords led to different types and number of contributions retrieved. Overall, by summing up all the results obtained in different search runs, a total of around 100 publications, excluding repetitions, were found. Abstracts and/or summaries of all the retrieved documents were initially read in order to evaluate their worthiness of further examination. Obviously, some papers were recognised to be more significant than others for the purposes of the present study. In particular, those contributions addressing CBEC without analysing logistics related issues or not focussed on our geographical region of interest were discarded. Conversely, the most recurrent papers (i.e. the ones resulting from multiple searches, as a possible indication of their relevance) which were specifically tailored on both logistics and Greater China were kept for review. Of the initial group of papers, more than 50 were carefully read to evaluate their inclusion in the review. This process led to the final selection of the 32 most pertinent contributions which are discussed in the review section. The others, when deemed however relevant or useful, but not dealing with the "core" topics of the review are referred to in other sections of the study. 


\section{Phase 2: Literature Analysis}

In this phase, a careful examination of previous literature review methods was conducted. No papers of this type were found on the same subject of this review, therefore other topics were considered, including for example literature reviews by Carter et al., 2007; Ghadge et al., 2012; Meixell and Norbis, 2008; Natarajarathinam et al., 2009; Pettit and Beresford, 2009. In line with the referred studies, the following dimensions were used to classify and review the papers, namely:

(i) Main features of the article (i.e. year of publication, name of journal or conference, name and number of authors, nationality of authors)

(ii) Geographical focus

(iii) Methods used in the papers

(iv) Main themes tackled

This structure helped systematically categorise contributions and was functional to the identification and discussion of key topics.

\section{Phase 3: Hints for future research}

In this stage, gaps identification naturally emerged from the analysis of the extant literature. More specifically, the first step implied discussing the major issues and shortfalls of existing contributions. These were identified as weakly covered or totally uncovered research areas. Starting from the identified gaps, a proposal of future research directions was postulated. In this process, the authors referred to literature published on related topics, i.e. logistics and supply chain management, e-commerce, internationalisation. Within this literature, we selected the topics that we considered to be more relevant in a CBEC context and adequately described how they could be approached in order to generate further knowledge on the topic of CBEC logistics to Greater China.

\section{Review of literature}

Main features of the articles and geographical focus

Table 1 reports the main features of each selected article and the methodology adopted in the analysis. 
As common in literature analyses, the contributions are presented chronologically in order to show the evolution of the topic over time. In our case, such order also helps highlight how recent the interest in this subject is.

Around $66 \%$ of the papers was published starting from 2010, and more than half (i.e. 56\%) refers to 2013 onwards. This increase in interest from the academic community can be explained mainly as a reflection of the of $\mathrm{B} 2 \mathrm{C}$ e-commerce growth in China.

However, another peak, despite smaller, is present in correspondence of the years 2002-2003. This is mainly the effect of two factors. On the one hand, 2001 is the year China entered the World Trade Organisation (WTO) thus provoking a sustained debate on the effects this would bring to the economy. On the other hand, there might be some lag effects of the e-commerce bubble burst in 2000 which produced an ever-growing interest in the topic.

As for the type of source, some of the most recent and appropriate contributions were found in the form of conference papers, which represent $16 \%$ of the reviewed sample. Regular papers still are the majority, representing $75 \%$ of the contributions, while the remaining $9 \%$ refers to some particularly suitable book chapters.

As for the published papers, they are contained in 18 different scientific journals. The majority (68\%) comes from international journals such as International Journal of Physical Distribution and Logistics Management, International Journal of Logistics Research and Applications, International Journal of Production Economics, Transport Policy. Still, a few journals "focussed" on the Asia-Pacific region (6\%) (e.g. Journal of Contemporary China, Journal of the Chinese Institute of Industrial Engineers) are present as well. As for the selected conference proceedings, they mainly refer to events hosted in China.

Additional information was collected regarding the Country of origin of the authors. Table 1 reports the nationality of just the first author. By looking at that, we can observe that the clear majority of contributions (i.e. 69\%) comes from scholars of the Greater China (more specifically $56 \%$ of authors are Chinese, $10 \%$ come from Hong Kong and 3\% from Taiwan). The rest still predominantly comes from the Asia Pacific region, i.e. from Australia, Singapore, Malaysia and South Korea. Together, these researchers account for $83 \%$ of the sample. The only western Countries represented in the analysis are USA and Canada (17\%). Nonetheless, in many of these cases research is conducted in cooperation with Asian scholars as second or third authors. This leads to the observation that the interest about CBEC logistics in China is still predominantly confined in the reference geographical area. We are therefore dealing with a theme whose knowledge is not yet widely shared or diffused. This result looks quite 
surprising, if we consider that research by foreign scholars could be particularly useful for their local companies interested in embracing CBEC to China.

Another monitored dimension is the geographical focus of the articles. Since this study is already geographically limited to the Greater China area, studying the geographical focus simply means observing how papers are "distributed" within the region. zhangIt can be noted that a few contributions focus on Greater China as a unique entity (22\%), while the majority still tends to analyse each Country separately (78\%), with contributions on Mainland China largely overcoming the ones focused on Taiwan or Hong Kong.

\section{Methods used in the papers}

In the same Table 1 the main methods used in the retrieved studies are reported, based on Meixwell and Norbis (2008). When more than one method was adopted, the prevalent one was reported. It can be observed that there is not a prevailing methodology.

$28 \%$ of the papers is based on empirical studies in the form of either case studies (19\%) or surveys (9\%). These are, for instance, the cases of Daly and Cui (2003) who addressed the main challenges of China's logistics consequent to the development of e-commerce by means of case studies, or Zhang and Figliozzi (2010) who conducted a survey to investigate the effects that inefficiencies of the Chinese transportation industry have on cross border trades.

Another $22 \%$ of publications presents general reviews while $13 \%$ shows conceptual frameworks on a handful of different topics, ranging from general overviews of logistics development in China (Goh and Ling, 2003) to the analysis of the third-party logistics service provider industry (e.g. Tian et al., 2010), to more specific descriptions of CBEC logistics in China (Jiao, 2015).

Then, around $28 \%$ of papers is based on analytical or mathematical models. Among these, $\mathrm{Wu}$ and Cheng (2006) and Wang et al. (2007) addressed the issue of e-commerce reverse logistics in Greater China, whereas Zhang and Zhang (2013) assessed the environmental impacts of alternative delivery systems in China. Three literature reviews (i.e. 9\%) were also examined, two of which are very recent (i.e. from 2013 on). These mainly deal with the analysis of the logistics and e-commerce industry in China. More in detail, Jiang and Prater (2002) discussed three major forces impacting China's logistics environment, namely economic growth, e-commerce and internationalisation. However, these phenomena were treated separately. For instance, the combined effect of e-commerce and international business on logistics was not examined. Similarly, Mahpula et al. (2013) and Liu (2014) mentioned several relevant aspects for China's logistics industry, including technology, e-commerce and 
international trade, but still regarded them rather separately. Therefore, no specific literature reviews on $\mathrm{CBEC}$ were found.

\section{Focus of the papers}

In order to provide a picture as much comprehensive and clear as possible, the papers were analysed on a double level. The first level aims at classifying contributions on a twodimensional matrix according to their scope. More in detail, the authors clustered the papers along the following axes:

(i) Geographical focus $(G F)$ - papers with a "wide" GF are the ones considering all the member Countries of Greater China in an integrated manner. Conversely, the authors labelled as "narrow" those contributions specifically focused on a single Country.

(ii) Logistics focus $(L F)$ - papers that analyse logistics in connection with at least another significant "topic" influencing CBEC, such as e-commerce marketplaces, payment systems, policy and legal implications have a "wide" LF. A "narrow" LF conversely characterises papers focussed only on the analysis of logistics-related issues.

The GF dimension serves the scope to deepen the analysis on the relations among Greater China Countries and the consequent implications for CBEC. The LF dimension is instead useful if we consider that logistics is a crucial aspect but not the only one to be correctly configured for the CBEC initiative to be successful.

Figure 1 shows the distribution of papers in each quadrant of the classification matrix.

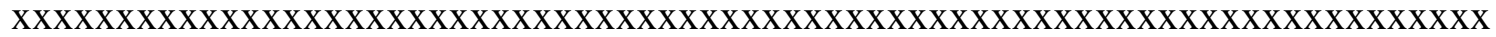

Take in Figure 1

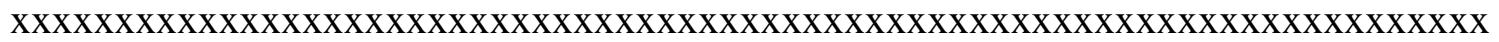

The majority of papers (i.e. 53\%) is in the bottom-left quadrant, meaning that the most common approach in the retrieved articles is to be very focussed on logistics and specifically analyse it with reference to a single Country. In $90 \%$ of cases China is under investigation, rather than Hong Kong or Taiwan. Being focussed often implies greater depth of the study. This is for instance the case of Jiang and Prater (2002) who performed a comprehensive analysis of Chinese logistics, wisely identifying some of the main issues of the future logistics scenario, e.g. immature infrastructure, the rising trend of online commerce and the difficulty to 
effectively ship products in a timely manner. With a similar depth, Wang et al. (2007) specifically focussed on reverse logistics for the Chinese B2C e-commerce market by modelling a new location-inventory policy.

The remaining papers (i.e. 47\%) are almost equally split between the bottom-right region (wide GF- narrow LF) and the upper-left one (narrow GF- wide LF). Among the contributions focussed on logistics for the whole Greater China, Cui et al. (2012) analysed the enablers and impediments of innovation in the third-party logistics industry of Greater China.

Coming to papers that analyse logistics paired with additional topics (narrow GF - wide LF), some of the most frequently discussed strategic areas, beside logistics, in general literature about CBEC include:

(i) legal aspects of $C B E C$, e.g. customs and duty regimes and tax laws (e.g. Bieron and Ahmed, 2012; Polanski, 2002; Teltscher, 2002 ).

(ii) marketing and branding issues (e.g. Guercini and Runfola, 2015) together with cultural aspects (e.g. Azar and Drogendijk, 2016).

(iii) online payment systems (e.g. He et al., 2006; Miao and Jayakar, 2016)

(iv) e-commerce platforms (e.g. Zhang and Huang, 2015; Dehui et al., 2016)

Among the papers with narrow GF and wide LF selected for this review we find $\mathrm{Ng}$ (2009), who investigated the complex relationship between e-commerce logistics and regulations analysing the main barriers to effective policy implementation in the Pearl River Delta Region in China, while Yang et al. (2014) explored four factors which may affect the entry mode of foreign SMEs to the Chinese e-commerce market, namely e-marketing, electronic payment, electronic customs and international logistics. Overall, nearly $75 \%$ of the papers with a wide LF discusses at least two topics beside logistics, with legal aspects and payment systems being the most frequent.

No papers were found in the upper-right quadrant (wide GF-wide LF) category, as a sign that more comprehensive models analysing $\mathrm{CBEC}$ to China from a multidimensional perspective and accounting for regions other than the Mainland are still missing Despite beneficial, such exhaustiveness is however hard to reach as the most appropriate trade-off between the width and depth of the analysis needs to be found.

\section{Main themes tackled}

The second level of analysis goes deeper in detail of the specific themes tackled in the papers. In this step, the following recurring themes were identified: 
(i) The development of logistics industry in Greater China

(ii) CBEC logistics in Greater China

(iii) Taiwan and Hong Kong as logistics “supporters” of Mainland China

\section{The development of the logistics industry in Greater China}

Contributions in this category have similar structures, starting with a description of the historical evolution of China, highlighting its still undergoing transition from a fully stateowned economy to a free market economy, and then analysing some specific subtopics of logistics management. Among these, the authors found transportation and warehousing (e.g. Goh and Ling 2003, Lean et al., 2014, Yan and Wang, 2015), third-party logistics (e.g.Tian et al., 2010; Cui et al., 2012; Gunasekaran and Ngai, 2003) and reverse logistics (e.g. Wang et al., 2007).

There is quite an agreement in the extant literature that the Chinese logistics scenario is highly complex. More specifically, the main challenges were effectively summarised by Zhang and Figliozzi (2010), who listed, among others, high costs and low efficiency, congestion (i.e. insufficient structure to face the increasing demand of booming economy), lack of integrated intermodal transport network, low usage of advanced technologies. They stated that these characteristics complicate international trade and heavily impact transport performances. In particular, freight rates, transit time and reliability were identified as key transport performance indicators, able to affect transport mode decisions.

Jiang and Prater (2002) underlined that the Chinese logistics landscape has unique characteristics. Its peculiarity is not only due to the vast geographical extension and diversity of the territory and its relatively poor infrastructure but also to some specific cultural features that should be considered even in logistics or supply chain-based research. This is the example of Guanxi, a Chinese concept to refer to the importance of personal relationships even in business partnerships or collaborations. Among others, Daly and Cui (2003), Jiang and Prater (2002), Liu (2014), and Zhang and Figliozzi (2010) made explicit reference, in their papers, to the importance of this cultural trait in logistics. Another key observation, probably adding complexity to the situation is the one noted by Mahpula et al. (2013). They highlighted a core concern for research in China logistics is the predominant focus of Chinese scholars on the "physical movement of goods" rather than on a more comprehensive supply chain perspective, as the term logistics actually means for international researchers. This implies the greatest emphasis is placed on freight transportation activities rather than on supply chain management. 
Adopting an extended view (i.e. supply chain based) could help get a more strategic and integrated perspective in facing the complex logistics and cultural challenges of the region.

\section{CBEC logistics in Greater China}

Many authors have acknowledged how the advent of e-commerce has profoundly affected logistics in China. Jiao (2014) for instance recognised that a developing e-commerce market heavily depends on logistics for the successful execution of online transactions. Being such an essential driver both for cost reduction and for the correct fulfilment of orders, logistics is gradually becoming the core competence Chinese e-commerce companies need to compete on. In this context, Choy (2014) suggested that the adoption of technology in the logistics and distribution operations can enhance logistics service quality thus nurturing competitiveness.

However, the consequences of e-commerce development have massive effects. The digital transformation of China is indeed recognised as a true revolution, able to change the daily life of citizens and affect the distribution models with impressive opportunities also for incremental cross border activities (Jiao, 2015).

Some authors specifically studied the relation between e-commerce and logistics in a cross border context. For instance, Shuyan and Lisi (2013) stressed the problem related to the excessive length of the order cycle for international e-commerce deliveries. They stated this could be solved by building overseas warehouses, which however imply higher costs. After examining pros and cons of warehouse building, they proposed some suggestions on how to sustain warehousing development. In this regard, Yan and Wang (2015) described the development of Shanghai's free trade zone, which was established together with other free trade zones by the Chinese Central Government in order to support the growth of global trade. Free trade zones are indeed governed by a series of rules that simplify, among others, warehousing and transportation activities.

Yang et al. (2014) added that the logistics capabilities of a company are among the factors affecting the selection of the entry mode to China. Their study focussed on SMEs indeed showed that companies who are too weak at cross border operations and logistics typically opt for selling through third party e-commerce platforms.

More recently, Ai et al. (2016) used data from the Ministry of Commerce to compare logistics performances of CBEC across multiple industries. They decided to analyse the determinants of logistics performances because logistics is the concluding part of a CBEC experience (i.e. taking place after sale and payment) and is therefore crucial for the successful fulfilment of CBEC orders. The authors considered some factors (e.g. regulations, cross border 
payments, electronic clearance) that could influence logistics performances and empirically tested the existence of any statistically significant relationship.

Similarly, in their study, Wang et al. (2015b) investigated the factors affecting international logistics performance and their relationships, finding for instance that laws and regulations affect international logistics performance and cross-border payments, electronic clearance and technology application level are mediating factors in the relationship. This implies laws should be set to regulate CBEC.

Last, Zhang and Zhang (2013) specifically considered environmental issues. They recognised that China has the highest carbon dioxide $\left(\mathrm{CO}_{2}\right)$ emissions in the world, of which a significant part comes from logistics activities. They also compared alternative delivery methods in Chinese e-commerce while confronting results with those of foreign Countries.

\section{The role of Taiwan and Hong Kong as logistics "supporters" of Mainland China}

This study also tries to understand the logistics linkages and opportunities stemming from the neighbour Countries of Mainland China in order to derive useful hints from a CBEC perspective.

In this regard, the topic does not have extensive coverage in the literature, however some of the analysed authors seem to agree on the central role that Taiwan and Hong Kong could play as additional locations for logistics facilities or simply acting as transit hubs in an international context due to their proximity to the Mainland.

Hou and Trappey (2002) were among the earliest recognisers that Taiwan was transforming into an ever-growing consumer economy. This led to the development of modern distribution channels not only for the locals, but also for the surrounding region and for the global marketplace, in order to maintain international competitiveness. By using multiple case studies, the authors demonstrated the increasingly active role of Taiwan as a global logistics distribution centre, where international companies and logistics service providers have been investing to locate their logistics infrastructures, including hubs or warehouses.

Zhang (2003) discussed conversely the role of Hong Kong as a regional and international air cargo hub in the context of both China and the Asia-Pacific region. He furthermore highlighted the connections between Taiwanese companies and Hong Kong, as many of the firms with export operations in Mainland China started to distribute their products through hubs located in Hong Kong.

$\mathrm{Wu}$ and Cheng (2006) also recognised that the establishment of logistics and distribution trading hubs is a hot topic in Asia. They analysed this issue by focussing on reverse logistics. 
By studying the characteristics and challenges of reverse logistics in China, Taiwan, and Hong Kong, they highlighted how the high levels of uncertainty and unpredictability can have an impact on the cost effectiveness of such activities.

More recently, Wang (2015) specifically focussed on similar topics explicitly including a B2C e-commerce perspective. He stressed how the rapid development of e-commerce, the high variability and diversity in customer demand and need for timeliness is pushing for higher requirements in logistics services. In the study, he evaluated the logistics performances of an e-commerce company distribution centre in China and came up with a series of suggestions on how to manage e-commerce logistics by preserving performances. Suggestions included the construction of self-controlled logistics systems (e.g. warehouses or hubs, despite the higher cost to gain control over the quality of the process) or, as an alternative, the intensification of cooperation with third-party logistics service providers.

Table 2 summarises the main themes arising in the literature and identifies the contributions tackling each of them.

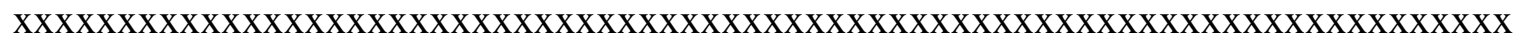

Take in Table 2

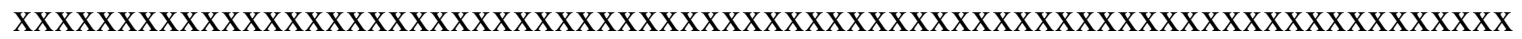

\section{Discussion of key issues}

Considering the presented review, the authors can observe several lacks in the academic literature of CBEC logistics to China.

The main consideration to make is that literature is still quite fragmented and needs to be reinforced. More specifically, existing contributions seem to be predominantly descriptive and general. This approach helps getting familiar with the research field, however it does not help getting more precise insights on how the complexities in managing CBEC logistics to Greater China, as identified in the introduction of the paper, should be addressed. The present section aims therefore to (i) identify the key topics to be investigated in this area and (ii) highlight how they could be explored. More precisely, a roadmap for building future research in this field is provided, starting from the definition of a specific research gap. The proposed framework identifies two "core" streams for future research and two "related" streams. Within the core ones, a suggestion of possible specific themes to tackle is provided. The framework is pictured in Figure 2 and thereafter described. 
In order to produce research that allows providing more specific support to players interested in embracing CBEC to China, the authors believe two main issues should be addressed in the first place, i.e. distribution network design and logistics outsourcing. These themes were identified by relying on literature produced in fields related to CBEC logistics, i.e. logistics and supply chain management, e-commerce, international business, and that could therefore reasonably be extended to a CBEC logistics context.

The first core research stream deals with the distribution network design in the context of CBEC. An important aspect for CBEC logistics indeed regards the topic of designing a global distribution network to deliver the products, i.e. deciding how to shape the distribution structure in terms of type, size, number and location of echelons as well as transportation modes (Ambrosino and Scutella, 2005; Mangiaracina et. al., 2015b). In this regard, research specific on e-commerce logistics to China is relatively scarce. Moreover, the authors feel that a deeper consideration of the geography of China, with more in depth descriptions of the diverging features of each area would be of high importance in the eye of a foreign western company willing to invest in a CBEC initiative. Distribution network design-related choices are indeed driven by different contextual factors (e.g. product, demand features, geographical location) and their importance is also linked to their strong impact on supply chain performance in terms of both logistics costs and customer service level (Mangiaracina et al., 2015b).

Due to the different choices to be made and the enormous variety of available network alternatives, distribution network design is a very complex task. However, the first factor to consider in this sense is that distribution network design should be specific to the distribution problem faced. Therefore, it is highly important that future research tries to focus on industry or product-specific studies. One of the key lacks of current literature in the authors' view is indeed the scarce consideration of industry related aspects. Only a few of the consulted contributions consider a specific industry (i.e. most often books or grocery), while the others tackle themes very generally, with no specific reference to a category of products. Also, more specific attention should be posed to those industries that appear more promising for an ecommerce initiative, such as the apparel industry, which is also particularly interesting to investigate due to its complex logistics requirements (Ghezzi at al., 2012). 
Also, the required service level (dependent on local customers shopping habits) should be considered. The service level, defined as the delivery time to the customer, is indeed extremely important since it can act as a constraint on the adoptable logistics solutions.

However, it is important not only to consider network design issues within China but also to examine possibilities to rely on facilities outside China and efficiently organise transportation across the nodes of the network. In this regard, a deeper investigation on the role of Taiwan and Hong Kong as distribution hubs for the Mainland would be needed. Regarding this topic, some contributions stress how helpful considering them as locations for distribution centres or hubs would be. Still, more research should be developed in the direction of understanding the real costs and benefits of such an approach as well as examining how to best implement a distribution network of this type by better investigating connections between Mainland China, Taiwan, Hong Kong or even other neighboring Asian Countries.

The second core research stream is related to logistics outsourcing. It is widely acknowledged in logistics-related literature that, since handling online orders often requires totally new distribution systems, logistics capability and logistics outsourcing are of outmost importance (Cho et al., 2008). In a CBEC environment, the question whether companies have enough competences to directly manage logistics is even more crucial. Due to the specificity of the Chinese market, it is likely that many the companies have to rely on specialised thirdparty logistics service providers, at least in the initial phase of their investment. If they opt for an outsourcing solution however, the benefits deriving from simplified processes are counterbalanced by (i) the possible reduction of control and visibility over the processes and (ii) the increase in the effort to manage the relationship with the providers. These two topics are therefore suggested as interesting areas to investigate within logistics outsourcing. Future studies able to provide a measure of these "intangible costs" of contract logistics could be of help in supporting the decision about the acceptable outsourcing level for CBEC in China.

However, logistics is not the only element to consider when planning a CBEC investment to China. As previously mentioned, many other elements contribute to the successful execution of CBEC. It would be partial to analyse logistics without considering the mutual influences between, for instance, logistics and regulations, marketing or platform selection. In addition, due to the novelty of CBEC, the fast-changing Chinese e-commerce market, the uncertainty about future scenarios and evolutions, it would be partial as well not to consider risk-related issues affecting CBEC logistics to China. These considerations motivate why we deem appropriate to also suggest two related research streams as future development paths. They are 
defined as "related" because they derive from the intersection of logistics and other research fields, as described below:

(i) Risk Analysis of logistics supporting a-CBEC initiative in China: The theme of logistics and supply chain risk evaluation seems rather underdeveloped in a CBEC perspective. However, when internationalising, companies need to estimate many variables and face the consequent uncertainties. As acknowledged by Pezderka and Sinkovics (2011), understanding the risks of virtual internationalisation processes is of outmost importance for the sustainability of companies' competitive advantage. While different tools supporting decision making under uncertainty exist and have occasionally been applied to internationalisation processes (e.g. Figueira-de-Lemos et al. 2011), no contributions of this type are available in the context of CBEC nor do they specifically tackle logistics- related risk factors.

(ii) Need of more "inclusive" studies, which analyse logistics in connection with other strategic pillars of a CBEC initiative: By taking the perspective of a foreign company willing to embrace a CBEC initiative, the authors also feel a more strategic perspective, by considering logistics in relation with other functions, e.g. finance, marketing, legal, is key. Among these, legal issues have a preeminent role, as the coordination between different legal systems can affect several procedures including, among others, electronic customs procedures. This in turn impacts logistics performances (Ai et al., 2016). Moreover, the Chinese legal framework related to e-commerce and cross border e-commerce is undergoing important modifications these months, as witnessed, for instance, by the recent circular 18 on Taxation Policy of CBEC imports (Paolucci, 2016). Understanding how legal and policy interventions can influence logistics management in such an evolving environment is a key element to investigate. While a wider ranging approach, which analyses connections of logistics with legal issues, is present in some contributions related to China, no similar studies could be retrieved with reference to Greater China. This gap should not be underestimated because, while a foreign retailer might think China and Hong Kong have similar legal systems, this is not the case and differences should be correctly pointed out in future studies.

One last consideration in our discussion of key issues regards the authorship of extant literature. The study has found that the great majority of publications on CBEC in China are indeed produced by Chinese or however Asian scholars. On the one hand this is expectable, as authors from those Countries are assumed to "feel" the issue more, access data and information more easily and accurately, and have more chances to observe and study the phenomenon. On the other hand, China's international role has undergone a profound evolution over time. While in the past China, but also Hong Kong and Taiwan, were predominantly seen as manufacturing 
and exporting Countries (e.g., Chen et al., 2004; Leung et al., 2002) their transformation into consumer Countries is progressively being acknowledged (e.g. Tongzon and Nguyen, 2009; Wang et al., 2015b; Yang and Shen, 2015; Zhenhua and Qiang, 2015, Zhang, 2015). This also implies CBEC is more and more enabling China to be not only an importing, but also an exporting Country. Therefore, larger interest from "foreign" scholars is expected and desirable in the future. In other words, in the authors' opinion, the need to make knowledge about this topic more shared and diffused, also through international research collaborations, is emerging and should be further enhanced.

\section{Conclusions}

Given the rising importance of CBEC for the Chinese market and the relevance of logistics for the successful implementation of an initiative of this kind, the aim of this paper was to identify important areas for future research by relying on a review of the literature about CBEC logistics to China. A specific focus was made on the logistics role played by Taiwan and Hong Kong as parts of Greater China, in this frame. The analysis is based on a set of 32 selected papers published from 2002 to 2016 in peer-reviewed international journals. A minor part of the contributions is constituted by book chapters and international conference papers. Although "only" 32 publications were included in the review, the authors believe that the number of contributions reviewed in this study is adequate given indeed the novelty of the topic and the focus on a circumscribed, despite promising, topic. Moreover, previous contributions addressing very specific research themes considered a similar number of papers (e.g. Cagno et al., 2013, included around 30 papers in their review on the economic evaluation of Occupational Safety and Health, while Perego et al., 2011, examined around 40 in their analysis of ICT for logistics and freight transportation).

No previous reviews dealing with the same topic of this study were found in literature, i.e. the combination of logistics, internationalisation and e-commerce in China. Some literature reviews were found addressing the themes of logistics and/or e-logistics in China. Those were included in the review as they revealed precious information about the specific characteristics of the region which should be posed to the attention of foreign decision makers willing to enter the promising Asian e-commerce market through online channels.

This review indeed was carried out mainly to the benefit of scholars and practitioners who are interested in analysing the phenomenon from a western perspective.

The review section was organised into three main sub-sections, namely (i) the discussion of the main characteristics (i.e. year of publication, journal or conference title, nationality of 
authors and geographical focus), (ii) the adopted research method(s) and (iii) the scope and the main themes addressed in the papers.

The articles are relatively recent (66\% percent of the papers were published from 2010 onward) and the research is mainly conducted by Chinese or Asian researchers as a sign that knowledge and interest in the topic is still localised.

In terms of the methodologies used, $28 \%$ is based on empirical studies conducted in the form of case studies or surveys, $22 \%$ of publications presents general reviews and 13\% conceptual frameworks. Then, around $28 \%$ of papers shows analytical or mathematical models.

With regard to content, papers were classified according to two dimensions. Results revealed that current research is still predominantly focused on logistics within a single nation, while more comprehensive studies both in terms of LF and GF are still missing. Coming to the topics, a series of themes were identified, namely (i) the development of logistics industry in Greater China; (ii) CBEC logistics in Greater China; (iii) Taiwan and Hong Kong as logistics "supporters" of Mainland China. This paper has both academic and practical/managerial implications. From an academic viewpoint, this study gathers the main body of knowledge on logistics supporting CBEC. This topic is receiving increasing attention, but is not mature yet, as witnessed by the relatively limited amount of publications produced. Since this is a rising topic, well established research streams still need to be built, and the authors are confident that such field will open the doors to many interesting research opportunities. In this regard, the paper specifically suggests and discusses key topics to address in future research. Two core and two related research streams are suggested as priorities and reasons are provided in the analysis. The authors do not believe such streams are the only important ones to tackle. However, they believe these areas are the ones most likely to produce studies able to guide foreign companies through informed decision making processes regarding CBEC logistics to Greater China. From a managerial perspective, this study helps export and/or logistics managers identify the key challenges of managing logistics to support CBEC to an attractive yet complex region as Greater China is. More in detail the following major "take-aways" could be identified:

(i) Chinese logistics industry is very peculiar, not only for its not fully developed condition, but also because of some typical cultural attitudes that should be taken into account when doing business in China, e.g. the Guanxi concept;

(ii) In an e-commerce environment, the quality of service is getting increasing importance and is often stimulating attention to performances and push to innovation, especially in the third-party logistics industry; 
(iii) In order for the logistics of a CBEC to be effective, companies should consider the possibility to establish partnerships with existing third-party logistics service providers and/or identify most appropriate locations for the distribution network. Effective options include Hong Kong and Taiwan for their proximity and increasing integration with the Mainland.

This study has however uncovered many shortfalls and open research areas in this field which were listed in the previous section. Stemming from those gaps, the present paper can be seen as a starting point to produce more research on this still largely unexplored topic.

\section{References}

Ai, W., Yang, J., and Wang, L. (2016), "Revelation of cross-border logistics performance for the manufacturing industry development", International Journal of Mobile Communications, Vol. 14, No. 6, pp. 593-609.

Ambrosino, D. and Scutella, M.G.(2005), "Distribution network design: new problems and related models", European Journal of Operational Research, Vol. 165 No. 3, pp. 610-624.

AT Kearney (2014), “China's e-commerce market in 2014: the logistics challenges" [online report], available at http://bit.ly/2fzMYHg (accessed 19 January 2017).

Azar, G. and Drogendijk, R. (2016), "Cultural distance, innovation and export performance: An examination of perceived and objective cultural distance", European Business Review, Vol. 28, No. 2, pp. 176-207.

Bieron, B., and Ahmed, U. (2012), "Regulating E-commerce through international policy: Understanding the international trade law issues of E-commerce", Journal of World Trade, Vol. 46, No. 3, pp. 545-570.

Cagno, E., Micheli, G.J.L., Masiand, D., and Jacinto, C. (2013), “Economic evaluation of OSH and its way to SMEs: A constructive review", Safety Science, Vol.53, pp.134-152

Carnwell, R. and Daly, W. (2001), "Strategies for the construction of a critical review of the literature", Nurse Education in Practice, Vol.1 pp. 57-63.

Carter, C.R., Kauffman, L. and Michel, A. (2007), "Behavioral supply management: a taxonomy of judgment and decision-making biases", International Journal of Physical Distribution \& Logistics Management, Vol. 37, No. 8, pp. 631-669.

Carter, C.R. and Easton, P.L. (2011), "Sustainable supply chain management: evolution and future direction", International Journal of Physical Distribution and Logistics Management, Vol. 41 No. 1, pp. 46-62.

Chen, J.C.H., Lin, B., Li, L., and Chen, P.S. (2004), "Logistics management in China: A case study of Haier", Human Systems Management, Vol. 23, No.1, pp. 15-27. 
Cho J.J., Ozment, J., and Sink, H. (2008), "Logistics capability, logistics outsourcing and firm performance in an e-commerce market", International Journal of Physical Distribution and Logistics Management, Vol. 38, No. 5, pp. 336 - 359.

Choy, K., Gunasekaran, A., Lam, H. et al. (2014), "Impact of information technology on the performance of logistics industry: the case of Hong Kong and Pearl Delta region", Journal of the Operational Research Society, Vol. 65, No. 6, pp. 904-916.

Cronin, P., Ryan, F., and Coughlan, M. (2008), "Undertaking a literature review: a step-bystep approach", British Journal of Nursing, Vol.17, pp.38-43.

Cui, L., Su, S.I., and Hertz, S. (2012), "Logistics innovation in China", Transportation Journal, Vol. 51, No. 1, pp. 98-117.

Daly, S.P., and Cui, L.X. (2003), "E-logistics in China: basic problems, manageable concerns and intractable solutions", Industrial Marketing Management, Vol. 32, pp.235-242.

Dehui, L. (2016), "A Comparative Analysis of B2C Cross-border E-commerce Platforms: the AliExpress and the DHgate", International Conference on Education, Management, Computer and Society, EMCS 2016.

Delfmann, W., Albers, S., and Gehring, M. (2002), "The impact of electronic commerce on logistics service providers", International Journal of Physical Distribution and Logistics Management, Vol. 32, No. 3, pp. 203 - 222.

Dobbs, R., Remes, J., Manyika, J., Roxburgh, C., Smit, S. and Schaer, F. (2012), "Urban world: Cities and the rise of the consuming class", Mckinsey Global Institute [online report], available at: http://bit.ly/2bPG7pT (accessed 20 November 2016)

eMarketer (2015), “China Ecommerce: 2015 Market Update” [report].

Figueira-de-Lemos, F., Johanson, J. and Vahlne, J. (2011), "Risk management in the internationalization process of the firm: A note on the Uppsala model", Journal of World Business, Vol. 46, No. 2, pp. 143-153.

Forrester (2015), "Forrester Research Online Retail Forecast, 2014 To 2019 (Asia Pacific)" [report].

Ghadge, A., Dani, S. and Kalawsky, R. (2012), "Supply chain risk management: present and future scope", International Journal of Logistics Management, Vol. 23, No. 3, pp. 313-339

Ghezzi, A., Mangiaracina, R. and Perego, A. (2012), "Shaping the e-Commerce logistics strategy: a decision framework", International Journal of Engineering Business Management, Vol. 4, No. 13, pp. 1-13.

Gessner, G.H., and Snodgrass, C. R. (2015), "Designing e-commerce cross-border distribution networks for small and medium-size enterprises incorporating Canadian and U.S. trade incentive programs", Research in Transportation Business \& Management, Vol. 16, pp. 84-94.

Goh, M. and Ling, C. (2003), "Logistics development in China", International Journal of Physical Distribution \& Logistics Management, Vol. 33, No. 10, pp.886-917.

Grubic, T. and Fan, I.S. (2010), "Supply chain ontology: review, analysis and synthesis", Computers in Industry, Vol. 61 No. 8, pp. 776-786 
Gomez-Herrera E., Martens, B., and Turlea, G. (2014). "The Drivers and Impediments for Cross-border e-Commerce in the EU", Information Economics and Policy, Vol.28, pp. 83-96.

Guercini, S., and Runfola, A. (2015). "Internationalization through E-commerce. The Case of Multi brand Luxury Retailers in the Fashion Industry", in Stöttinger ,B., Schlegelmilch , B.B., Zou, S. (Ed.), International Marketing in the Fast Changing World, Advances in International Marketing, Vol. 26, Emerald Group Publishing Limited, pp.15 - 31.

Gunasekaran, A., and Ngai, E.W.T. (2003), "The successful management of a small logistics company", International Journal of Physical Distribution \& Logistics Management, Vol. 33 No. 9, pp. $825-842$.

He, Q., Duan, Y., Fu, Z. \& Li, D. 2006, "An innovation adoption study of online e-payment in Chinese companies", Journal of Electronic Commerce in Organizations, vol. 4, no. 1, pp. 4869.

Hensher, D.A., Zhang, Z. and Rose, J. (2015), "Transport and logistics challenges for China: Drivers of growth, and bottlenecks constraining development", Road and Transport Research, Vol. 24, No. 2, pp. 32-41.

Hou, X.F. 2014, "Analysis on the situation of China's E-commerce logistics", Advanced Materials Research, pp.926-930.

Hou, J.L., and Trappey, C.V. (2002), "Connecting small and medium enterprises to the global market via the global logistics service chain-sector analyses and case studies", Journal of the Chinese Institute of Industrial Engineers, Vol.19, No.5, pp. 75-87

Jacques, M. (2012). "When China rules the world. The end of the western world and the birth of a new global order", Penguin Books, New York.

Jiang, B. and Prater, E. (2002),"Distribution and logistics development in China", International Journal of Physical Distribution \& Logistics Management, Vol. 32, No.9, pp. 783 - 798.

Jiao Z., (2014). "Development of E-Commerce Logistics in China", in Liu B. et al. (ed.), Contemporary Logistics in China. Consolidation and deepening, Springer.

Jiao, Z. (2015), "Modes and Development Characteristics of China's Cross-border Ecommerce Logistics" in Liu B. et al. (ed.), Contemporary Logistics in China. Proliferation and internationalisation, Springer.

Lean, H.H., Huang,W. and Hong, J. (2014)“Logistics and economic development: Experience from China”, Transport Policy, Vol. 32, pp. 96-104.

Leung, S.C.H., Wu, Y. and Lai, K.K. (2002), “A robust optimization model for a cross-border logistics problem with fleet composition in an uncertain environment", Mathematical and Computer Modelling, Vol. 36, No.11, pp.1221-1234.

Liu, X. (2014),"China-based logistics research: a review of the literature and implications", International Journal of Physical Distribution \& Logistics Management, Vol. 44, No. 5, pp. $392-411$. 
Lu, L. (2014), "Analysis into market layout of luxury e-commerce at home and abroad", Environment, Energy and Sustainable Development - Proceedings of the 2013 International Conference on Frontier of Energy and Environment Engineering, ICFEEE 2013, pp. 1035.

Mahpula, A., Yang, D., Kurban, A. and Witlox, F., (2013) “An overview of 20 years of Chinese logistics research using a content-based analysis", Journal of Transport Geography, Vol. 31, pp. 30-34,.

Mangiaracina R., Marchet A., Perotti S., and Tumino A., (2015a). "A Review of the Environmental Implications of B2c eCommerce: A Logistics Perspective", International Journal of Physical Distribution and Logistics Management, Vol.45, No.6, pp.565-591.

Mangiaracina, R., Song, G. and Perego, A. (2015b)," Distribution network design: a literature review and a research agenda ", International Journal of Physical Distribution and Logistics Management, Vol. 45, No. 5, pp. 506 - 531.

Meixell, M. J. and Norbis, M. (2008), "A review of the transportation mode choice and carrier selection literature", International Journal of Logistics Management, Vol. 19, No. 2, pp. 183211.

Miao, M., Jayakar, K. (2016). "Mobile payments in Japan, South Korea and China: Crossborder convergence or divergence of business models?", Telecommunications Policy, Vol. 40 No 2-3, pp. 182-196.

Natarajarathinam, M., Capar, I. and Narayanan, A. (2009), "Managing supply chains in times of crisis: a review of literature and insights", International Journal of Physical Distribution \& Logistics Management, Vol. 39, No. 7, pp. 535-573.

Ng, J.J.M. (2009), "Barriers to e-commerce policy in logistics: an exploratory study of the Pearl River Delta, China", International Journal of Logistics: Research and Applications, Vol. 12, No. 3, pp. 195-212.

Nielsen (2016), “China's E-Commerce Market: Untapped Potential for Global Companies" [online], available at http://sites.nielsen.com/newscenter/chinas-e-commerce-marketuntapped-potential-for-global-companies/ (accessed 22 January 2017).

Paolucci, F. (2016), "Changing Import Tax Policies for e-Commerce in China”, China Business Review, 05 August, available at: http://bit.ly/2jiiedF (accessed 02 December 2016).

Paypal (2014), "Modern Spice Routes. The Cultural Impact and Economic Opportunity of Cross-Border Shopping", [online report] available at http://bit.ly/2bOk42W (accessed 25 August 2016).

Perego, A., Perotti, S. and Mangiaracina, R. (2011), "ICT for logistics and freight transportation: a literature review and research agenda", International Journal of Physical Distribution \& Logistics Management, Vol. 41, No. 5, pp. 457-483.

Pettit, S. and Beresford, A. (2009), "Critical success factors in the context of humanitarian aid supply chains", International Journal of Physical Distribution \& Logistics Management, Vol. 39, No. 6, pp. 450-468. 
Pezderka, N., and Sinkovics, R.R. (2011), "A conceptualization of e-risk perceptions and implications for small firm active online internationalization", International Business Review, Vol. 20, No. 4, pp. 409-422.

Polanski, P.P. (2002), "A new approach to regulating internet commerce: Custom as a source of electronic commerce law", Electronic Communication Law Review, Vol. 9, No. 3, pp. 165205.

Ramanathan, R., George, J. and Ramanathan, U. 2014, "The role of logistics in E-commerce transactions: An exploratory study of customer feedback and risk", in Supply Chain Strategies, Issues and Models, Ramanathan R, and Ramanathan U. (Ed.), London, Springer, pp. 221-233.

Reuters. (2015). "China then and now", available at http://reut.rs/18gj5qv (accessed 18 November 2016).

Shuyan, C. and Lisi, X.. (2013). "Research on the Overseas Warehouse Construction of CrossBorder E-Commerce" in Wuhan $12^{\text {th }}$ International Conference on e-Business Proceedings, paper 77.Srivastava, S.K. (2007), "Green supply-chain management: a state-of-the-art literature review", International Journal of Management Reviews, Vol. 9, No. 1, pp. 53-80.

Teltscher, S. (2002), "Electronic commerce and development: Fiscal implications of digitized goods trading", World Development, Vol. 30, No. 7, pp. 1137-1158.

Tian, Y., Ellinger, A.E., and Chen, H. (2010) "Third-party logistics provider customer orientation and customer firm logistics improvement in China", International Journal of Physical Distribution \& Logistics Management, Vol. 40 No. 5, pp.356 - 376.

Tongzon, J. and Nguyen, O. (2009), "China's economic rise and its implications for logistics: The Australian case", Transport Policy, Vol. 16, No.5, pp. 224-231.

Tranfield, D.R., Denyerand, D. and Smart, P. (2003), "Towards a methodology for developing evidence-informed management knowledge by means of systematic review", British Journal of Management, Vol.14, pp.207-222.

Visser, JGSN and Nemoto, T (2002). "E-commerce and the consequences for freight transport". In E Taniguchi, and R.G. Thompson (Eds.), Innovations in freight transport, Boston: WITpress, pp. 165-193.

Wang, L. (2015), "Research on the Impact of E-commerce to Logistics Economy: An Empirical Analysis based on Zhengzhou Airport Logistics ", International Journal of Security and Its Applications, Vol.9, No.10, pp.275-286.

Wang, Z., Yao, D.Q., and Huang, P. (2007), "A new location-inventory policy with reverse logistics applied to B2C e-markets of China", International Journal of Production Economics, Vol. 107, No. 2, pp.350-363.

Wang, L., Chai, Y., Liu, Y. and Xu, Y. (2015a) "Qualitative Analysis of Cross-Border ECommerce Based on Transaction Costs Theory," in e-Business Engineering (ICEBE) 2015 proceedings of the IEEE 12th International Conference in Beijing, 2015 pp. 166-172.

Wang, L., Yang, J., Yin, S. (2015b), "Electronic commerce international logistics performance influence factor analysis", International Journal of Mobile Communications, Vol.13, No. 5. 
Winters, B. (2016), "Now is not the time to sell China short", Financial Times, 07 June, available at: http://on.ft.com/2cbfbEX (accessed 30 August 2016).

Wu, Y.C.J., and Cheng, W.P. (2006) "Reverse logistics in the publishing industry: China, Hong Kong, and Taiwan", International Journal of Physical Distribution \& Logistics Management, Vol. 36, No.7, pp.507 - 523.

Xu, S.X., Yan, X. \& Zheng, X. (2008), "Communication platforms in electronic commerce: A three-dimension analysis", Info, Vol. 10, No. 2, pp. 47-56.

Yan, W. and Wang, L. (2015), "Development of shanghai's free trade zone logistics", in Liu B. et al. (ed.), Contemporary Logistics in China. Proliferation and internationalisation, Springer.

Yang, Z. and Shen, Q. (2015), "Current Status and Trend Analysis of China's Import Crossborder E-commerce Development" in International Conference on Education Technology, Management and Humanities Science (ETMHS 2015)Proceedings, pp. 133-137.

Yang, J., Yang, L., and Yang, N. (2014), "The Factors Affecting Cross-border E-commerce Development of SMEs: An Empirical Study", in Wuhan $13^{\text {th }}$ International Conference on eBusiness Proceedings. Paper 12.

Zhang, A. (2003), "Analysis of an international air-cargo hub: the case of Hong Kong", Journal of Air Transport Management, Vol. 9, No.2, pp.123-138.

Zhang, Y. (2015), "Optimization methods for sustainable development of cross-border Ecommerce in China", in International Conference on Engineering Technology, Engineering Education and Engineering Management, ETEEEM 2014, pp. 1069.

Zhang, K., and Huang, L. (2015), "Research on Cross-border E-commerce platform selection in China small \& medium-sized enterprises", 10th IEEE Int. Conf. on Service Operations and Logistics, and Informatics, SOLI 2015 - In conjunction with ICT4ALL 2015, pp. 182-185.

Zhang, L., and Zhang, Y. (2013). "A Comparative Study of Environmental Impacts of Two Delivery Systems in the Business-to-Customer Book Retail Sector", Journal of Industrial Ecology, Vol. 17, No.3, pp. 407-416.

Zhang, Z. and Figliozzi, M.A. (2010), “A Survey of China's Logistics Industry and the Impacts of Transport Delays on Importers and Exporters", Transport Reviews, Vol. 30, No.2, pp.179194.

Zhenhua, Y. and Qiang, S. (2015), "Problems in Cross-border E-commerce Export Trade in China \& Countermeasure Analysis" in International Conference on Informatization in Education, Management and Business. 
Figure 1 - Focus of the papers

\begin{tabular}{|c|c|c|c|}
\hline & \multicolumn{3}{|c|}{ Geographical Focus (GF) } \\
\hline & Narrow & & Wide \\
\hline & \multicolumn{2}{|c|}{$\begin{array}{l}\text { Chen et al. (2004) } \\
\text { Ng (2009) } \\
\text { Wang et al. (2015b) } \\
\text { Yang and Shen (2015) } \\
\text { Yang et at. (2014) } \\
\text { Zhang (2015) } \\
\text { Zhenhaa and Qiang (2015) }\end{array}$} & \\
\hline 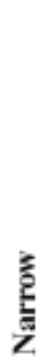 & $\begin{array}{l}\text { Cao and Xu (2013) } \\
\text { Daly and Cuí (2003) } \\
\text { Goh and Ling (2003) } \\
\text { Gunasekaran and Ngai (2003) } \\
\text { Hensher et al. (2015) } \\
\text { Jiang and Prater (2002) } \\
\text { Jiao (2014) } \\
\text { Jiao (2015) } \\
\text { Lean et al. (2014) }\end{array}$ & $\begin{array}{l}\text { Mahpula et al. (2013) } \\
\text { Tian et al (2010) } \\
\text { Tongzon and Nguyen (2009) } \\
\text { Wang (2015) } \\
\text { Wang et al. (2007) } \\
\text { Yan and Wang (2015) } \\
\text { Zhang and Figliozi (2010) } \\
\text { Zhang and Zhang (2013) }\end{array}$ & $\begin{array}{l}\text { Ai et al (2016) } \\
\text { Choy et al. (2014) } \\
\text { Cui et aL. (2012) } \\
\text { Hou and Trappey (2002) } \\
\text { Leung et al. (2002) } \\
\text { Liu (2014) } \\
\text { Wu and Cheng (2006) } \\
\text { Zhang (2003) }\end{array}$ \\
\hline
\end{tabular}

Figure 2 - Future research streams

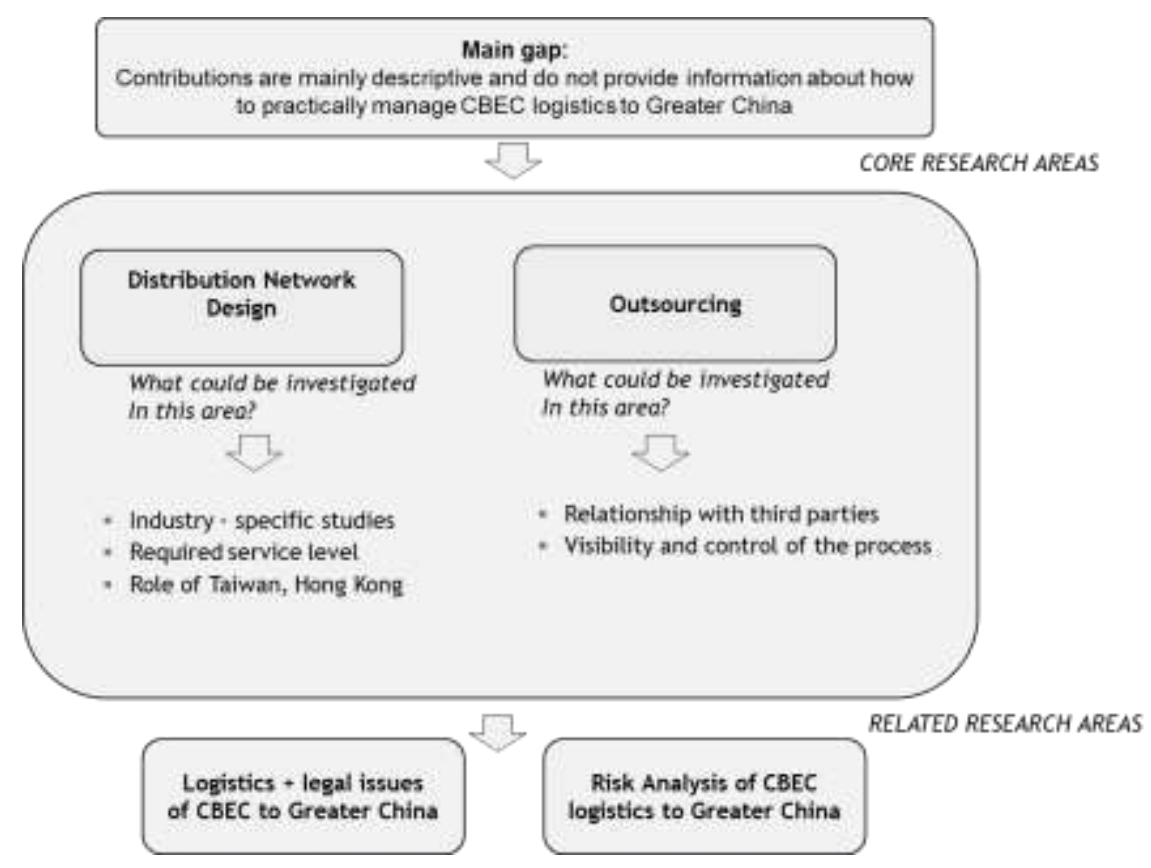




\begin{tabular}{|c|c|c|c|c|c|c|c|c|}
\hline No. & Author & Year & Country & Type of source & Name of Journal/Book/Conference & Title & Research Methods & Geographical focus \\
\hline 1 & Hou and Trappey & 2002 & Taiwan & Journal Paper & Journal of the Chinese Institute of Industrial Engineers & $\begin{array}{l}\text { Connecting small and medium enterprises to the global market via the global } \\
\text { logistics service chain - Sector analyses and case studies }\end{array}$ & Case study & Taiwan \\
\hline 2 & Jiang and Prater & 2002 & USA & Journal Paper & International Journal of Phisical Distribution and Logistics Management & Distribution and logistics development in China: The revolution has begun & Literature review & China \\
\hline 3 & Leung et al. & 2002 & Hong Kong & Journal Paper & Mathematical and Computer Modeling & $\begin{array}{l}\text { A Robust Optimization Model for a Cross-Border Logistics Problem with Fleet } \\
\text { Composition in an Uncertain Environment }\end{array}$ & Analytical model & Greater China \\
\hline 4 & Daly and Cui & 2003 & USA & Journal Paper & Industrial Marketing Management & $\begin{array}{c}\text { E-logistics in China: basic problems, manageable concerns and intractable } \\
\text { solutions }\end{array}$ & Case study & China \\
\hline 5 & Gunasekaran and Ngai & 2003 & USA & Journal Paper & Internationa Journal of Physical Distribution and Logistics Management & The successful management of a small logistics company & Case study & Hong Kong \\
\hline 6 & Goh and Ling & 2003 & Singapore & Journal Paper & International Journal of Phisical Distrtibution and Logistics Management & Logistics development in China & General Review & China \\
\hline 7 & zhang & 2003 & Canada & Journal Paper & Journal of Air Transport Management & Analysis of an international air-cargo hub: the case of Hong Kong & Conceptual model & Greater China \\
\hline 8 & Chen et al. & 2004 & USA & Journal Paper & Human Systems Management & Logistics management in China: A case study of Haier & Case study & China \\
\hline 9 & Wu and Cheng & 2006 & China & Journal Paper & International Journal of Phisical Distribution and Logistics Management & Reverse logistics in the publishing industry: China, Hong Kong and Taiwan & Analytical model & Greater China \\
\hline 10 & Wang et al. & 2007 & China & Journal Paper & International J Jurnal of Production Economics & $\begin{array}{l}\text { A new location-inventory policy with reverse logistics applied to B2C e- } \\
\text { markets of China }\end{array}$ & Analytical model & China \\
\hline 11 & Ng & 2009 & Hong Kong & Journal Paper & $\begin{array}{l}\text { International Journal of Logistics Research and Applications: A Leading Journal of Supply Chain } \\
\text { Management }\end{array}$ & $\begin{array}{l}\text { Barriers to e-commerce policy in logistics: An exploratory study of the Pearl } \\
\text { River Delta, China }\end{array}$ & Case study & China \\
\hline 12 & Tianetal & 2010 & China & Journal Paper & International Journal of Phisical Distribution and Logistics Management & $\begin{array}{l}\begin{array}{l}\text { Third-party logistics provider customer orientation and customer firm logistics } \\
\text { improvement in China }\end{array} \\
\text {. }\end{array}$ & Conceptual model & China \\
\hline 13 & Zhang and Figliozzi & 2010 & Australia & Journal Paper & Transport Reviews & $\begin{array}{l}\text { A Survey of China's Logistics Industry and the Impacts of Transport Delays on } \\
\text { Importers and Exporters }\end{array}$ & Survey & China \\
\hline 14 & Cui et al. & 2012 & China & Journal Paper & Transportation Journal & Logistics Innovation in China & Case study & Greater China \\
\hline 15 & Mahpula et al. & 2013 & China & Journal Paper & Journal of Transport Geography & $\begin{array}{l}\text { An overview of } 20 \text { years of Chinese logistics research using a content-based } \\
\text { analysis }\end{array}$ & Literature review & China \\
\hline 16 & Tongzon and Nguyen & 2013 & South Korea & Journal Paper & Transport Policy & China's economic rise and its implications for logistics: the Australian case & Analytical model & China, Australia \\
\hline 17 & Cao and Xu & 2013 & China & Conference Paper & 12th Wuhan International Conference on E-Business & $\begin{array}{l}\text { Research on the Overseas Warehouse Construction of Cross-Border E- } \\
\text { Commerce }\end{array}$ & General Review & China \\
\hline 18 & Zhang and zhang & 2013 & China & Journal Paper & Journal of Industrial Ecology & $\begin{array}{l}\text { A Comparative Study of Environmental Impacts of Two Delivery Systems in } \\
\text { the Business-to-Customer Book Retail Sector }\end{array}$ & Analytical model & China \\
\hline 19 & Lean et al. & 2014 & Malaysia & Journal Paper & Transport Policy & Logistics and economic development: Experience from China & Analytical model & China \\
\hline 20 & Choy et al. & 2014 & Hong Kong & Journal Paper & Journal of the Operational Research Society & $\begin{array}{l}\text { Impact of information technology on the performance of logistic sindustry: } \\
\text { the case of Hong Kong and Pearl Delta region }\end{array}$ & Survey & Greater China \\
\hline 21 & Yang et al. & 2014 & China & Conference Paper & 13th Wuhan International Conference on E-Business & $\begin{array}{l}\text { The Factors Affecting Cross-border E-commerce Development of SMEs-An } \\
\text { Empirical Study }\end{array}$ & Analytical model & China \\
\hline 22 & Jiao & 2014 & China & Book chapter & Contemporary Logistics in China. Consolidation and deepening & Development of E-Commerce Logistics in China & General Review & China \\
\hline 23 & Liu & 2014 & China & Journal Paper & International Journal of Phisical Distribution and Logistics Management & China-based logistics research: a review of the literature and implications & Literature review & Greater China \\
\hline 24 & Jiao & 2015 & China & Book chapter & Contemporary Logistics in China: Proliferation and Internationalization & $\begin{array}{l}\text { Modes and development characteristics of China's cross-border E-commerce } \\
\text { logistics }\end{array}$ & Conceptual model & China \\
\hline 25 & Zhang & 2015 & China & Conference Paper & $\begin{array}{l}\text { International Conference on Engineering Technology, Engineering Education and Engineering } \\
\text { Management }\end{array}$ & $\begin{array}{l}\text { Optimization methods for sustainable development of cross-border E- } \\
\text { commerce in China }\end{array}$ & Conceptual model & China \\
\hline 26 & Wang et al. & 2015 & China & Journal Paper & International Journal of Mobile Communications & $\begin{array}{l}\text { Electronic commerce international logistics performance influence factor } \\
\text { analysis }\end{array}$ & Survey & Many countries \\
\hline 27 & Yang and Shen & 2015 & China & Conference Paper & International Conference on Education Technology, Management and Humanities Science & $\begin{array}{l}\text { Current Status and Trend Analysis of China's Import Cross-border E- } \\
\text { commerce Development }\end{array}$ & General Review & China \\
\hline 28 & Hensher et al. & 2015 & Australia & Journal Paper & Road \& Transport Research: A Journal of Australian and New Zealand Research and Practice & $\begin{array}{l}\text { Transport and logistics challenges for China: Drivers of growth, and } \\
\text { bottlenecks constraining development }\end{array}$ & General Review & China \\
\hline 29 & Yan and Wang & 2015 & China & Book chapter & Contemporary Logistics in China: Proliferation and Internationalization & Development of shanghai's free trade zone logistics & General Review & China \\
\hline 30 & Wang & 2015 & China & Journal Paper & International Journal of Security and Its Applications & $\begin{array}{l}\text { Research on the Impact of E-commerce to Logistics Economy: An Empirical } \\
\text { Analysis based on Zhengzhou Airport Logistics }\end{array}$ & Analytical model & China \\
\hline 31 & Zhenhua and Qiang & 2015 & China & Conference Paper & International Conference on Informatization in Education, Management and Business & $\begin{array}{l}\text { Problems in Cross-border E-commerce Export Trade in China \& } \\
\text { Countermeasure Analysis }\end{array}$ & General Review & China \\
\hline 32 & Ai tet al. & 2016 & China & Journal Paper & International Journal of Mobile Communications & $\begin{array}{l}\text { Revelation of cross-border logistics performance for the manufacturing } \\
\text { industry development }\end{array}$ & Survey & China \\
\hline
\end{tabular}

Table 1 - Papers included in the literature review 


\begin{tabular}{|c|c|c|c|c|c|c|}
\hline No. & Author & Year & Title & $\begin{array}{l}\text { The development of the logistics industry in } \\
\text { Greater China }\end{array}$ & CBEC logistics in Greater China & $\begin{array}{l}\text { Taiwan and Hong Kong as logistics "supporters" of } \\
\text { Mainland China }\end{array}$ \\
\hline 1 & Hou and Trappey & 2002 & $\begin{array}{l}\text { Connecting small and medium enterprises to the global market via the global } \\
\text { logistics service chain - Sector analyses and case studies }\end{array}$ & & & $x$ \\
\hline 2 & Jiang and Prater & 2002 & Distribution and logistics development in China: The revolution has begun & $\mathrm{x}$ & $\mathrm{x}$ & \\
\hline 3 & Leung et al. & 2002 & $\begin{array}{l}\text { A Robust Optimization Model for a Cross-Border Logistics Problem with Fleet } \\
\text { Composition in an Uncertain Environment }\end{array}$ & & & $\mathbf{x}$ \\
\hline 4 & Daly and Cui & 2003 & $\begin{array}{c}\text { E-logistics in China: basic problems, manageable concerns and intractable } \\
\text { solutions }\end{array}$ & & $\mathbf{x}$ & \\
\hline 5 & Gunasekaran and Ngai & 2003 & The successful management of a small logistics company & $\mathbf{x}$ & & \\
\hline 6 & Goh and Ling & 2003 & Logistics development in China & $\mathbf{x}$ & & \\
\hline 7 & zhang & 2003 & Analysis of an international air-cargo hub: the case of Hong Kong & & & $\mathrm{x}$ \\
\hline 8 & Chen et al. & 2004 & Logistics management in China: A case study of Haier & $\mathrm{x}$ & & \\
\hline 9 & Wu and Cheng & 2006 & Reverse logistics in the publishing industry: China, Hong Kong and Taiwan & & & $\mathbf{x}$ \\
\hline 10 & Wang et al. & 2007 & $\begin{array}{l}\text { A new location-inventory policy with reverse logistics applied to B2C e- } \\
\text { markets of China }\end{array}$ & & $\mathbf{x}$ & \\
\hline 11 & $\mathrm{Ng}$ & 2009 & $\begin{array}{l}\text { Barriers to e-commerce policy in logistics: An exploratory study of the Pearl } \\
\text { River Delta, China }\end{array}$ & & $\mathbf{x}$ & \\
\hline 12 & Tian et al & 2010 & $\begin{array}{c}\text { Third-party logistics provider customer orientation and customer firm logistics } \\
\text { improvement in China }\end{array}$ & $\mathbf{x}$ & & \\
\hline 13 & Zhang and Figliozzi & 2010 & $\begin{array}{l}\text { A Survey of China's Logistics Industry and the Impacts of Transport Delays on } \\
\text { Importers and Exporters }\end{array}$ & $\mathbf{x}$ & & \\
\hline 14 & Cui et al. & 2012 & Logistics Innovation in China & $\mathrm{x}$ & & \\
\hline 15 & Mahpula et al. & 2013 & $\begin{array}{c}\text { An overview of } 20 \text { years of Chinese logistics research using a content-based } \\
\text { analysis }\end{array}$ & $\mathbf{x}$ & & \\
\hline 16 & Tongzon and Nguyen & 2013 & China's economic rise and its implications for logistics: the Australian case & $\mathbf{x}$ & & \\
\hline 17 & Cao and $\mathrm{Xu}$ & 2013 & $\begin{array}{l}\text { Research on the Overseas Warehouse Construction of Cross-Border E- } \\
\text { Commerce }\end{array}$ & & $\mathbf{x}$ & \\
\hline 18 & Zhang and Zhang & 2013 & $\begin{array}{l}\text { A Comparative Study of Environmental Impacts of Two Delivery Systems in } \\
\text { the Business-to-Customer Book Retail Sector }\end{array}$ & & $\mathbf{x}$ & \\
\hline 19 & Lean et al. & 2014 & Logistics and economic development: Experience from China & $\mathrm{x}$ & & \\
\hline 20 & Choy et al. & 2014 & $\begin{array}{l}\text { Impact of information technology on the performance of logistics industry: } \\
\text { the case of Hong Kong and Pearl Delta region }\end{array}$ & & $\mathbf{x}$ & \\
\hline 21 & Yang et al. & 2014 & $\begin{array}{c}\text { The Factors Affecting Cross-border E-commerce Development of SMEs-An } \\
\text { Empirical Study }\end{array}$ & & $\mathrm{x}$ & \\
\hline 22 & Jiao & 2014 & Development of E-Commerce Logistics in China & & $\mathbf{x}$ & \\
\hline 23 & Liu & 2014 & China-based logistics research: a review of the literature and implications & $\mathrm{x}$ & & \\
\hline 24 & Jiao & 2015 & $\begin{array}{c}\text { Modes and development characteristics of China's cross-border E-commerce } \\
\text { logistics }\end{array}$ & & $\mathbf{x}$ & \\
\hline 25 & zhang & 2015 & $\begin{array}{l}\text { Optimization methods for sustainable development of cross-border E- } \\
\text { commerce in China }\end{array}$ & & $\mathbf{x}$ & \\
\hline 26 & Wang et al. & 2015 & 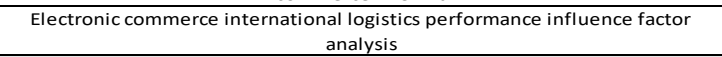 & & $\mathrm{x}$ & \\
\hline 27 & Yang and Shen & 2015 & $\begin{array}{c}\text { Current Status and Trend Analysis of China's Import Cross-border E- } \\
\text { commerce Development }\end{array}$ & & $\mathbf{x}$ & \\
\hline 28 & Hensher et al. & 2015 & $\begin{array}{c}\text { Transport and logistics challenges for China: Drivers of growth, and } \\
\text { bottlenecks constraining development }\end{array}$ & $\mathbf{x}$ & & \\
\hline 29 & Yan and Wang & 2015 & Development of shanghai's free trade zone logistics & & $\mathrm{x}$ & \\
\hline 30 & Wang & 2015 & $\begin{array}{l}\text { Research on the Impact of E-commerce to Logistics Economy: An Empirical } \\
\text { Analysis based on Zhengzhou Airport Logistics }\end{array}$ & & $\mathbf{x}$ & $\mathbf{x}$ \\
\hline 31 & Zhenhua and Qiang & 2015 & $\begin{array}{c}\text { Problems in Cross-border E-commerce Export Trade in China \& } \\
\text { Countermeasure Analysis }\end{array}$ & & $\mathbf{x}$ & \\
\hline 32 & Ai et al. & 2016 & $\begin{array}{c}\text { Revelation of cross-border logistics performance for the manufacturing } \\
\text { industry development }\end{array}$ & & $\mathbf{x}$ & \\
\hline
\end{tabular}

